\title{
Managing the boundaries between work and home: a study with expatriates
}

\author{
MARCOS ROBERTO Nóbrega ${ }^{1}$ \\ BRUNO FELIX ${ }^{1}$ \\ ${ }^{1}$ Fucape Business School / Programa de Pós-GraduaçÃo em Administração e Contabilidade, Vitória - ES, BraziL
}

\begin{abstract}
This study aims to understand the tactics that expatriates use to manage the interface between work and home. This qualitative study was performed using in-depth interviews later submitted to content analysis, with 64 male Brazilian expatriates. The results showed that expatriates manage the conflicts that may appear in relationships with social actors from the organizational (e.g., employers, customers, and suppliers) and home (spouse, children, and parents) domains by using boundary work tactics. The analysis revealed a list of tactics that allow the expatriates to integrate or segment the work and home domains. This study suggests how expatriates can actively interact with people from work and home domains in such a way that they can build and maintain better work and home relationships during the period they are living in other country. Additionally, companies should develop work-home policies that consider the preferences that an expatriate and his family have for integrating or segmenting work and home domains.
\end{abstract}

Keywords: Expatriates. Work-home balance. Boundaries. PE-Fit.

\section{Gerenciando os limites trabalho-lar: um estudo com expatriados}

\section{Resumo}

O objetivo deste estudo foi entender as táticas usadas pelos expatriados para gerenciar a interface trabalho-lar. Esta pesquisa qualitativa foi realizada por meio de entrevistas em profundidade com 64 expatriados brasileiros do sexo masculino, submetidas posteriormente a análise de conteúdo. Os resultados mostraram que os expatriados gerenciam os conflitos que podem aparecer nas relações com os atores sociais dos domínios organizacional (por exemplo, empregadores, clientes e fornecedores) e doméstico (cônjuge, filhos e pais) usando táticas de negociação de fronteiras entre esses domínios. A análise revelou uma lista de táticas que permitem aos expatriados integrar ou segmentar os domínios, bem como permitiu oferecer sugestões de como esses profissionais podem interagir ativamente para construir e manter o equilíbrio trabalho-lar durante esse período de alocação no exterior que lhes é tão exigente. Além disso, a pesquisa sugere que as empresas desenvolvam políticas de trabalho em casa que levem em conta as preferências que um expatriado e sua família têm para integrar ou segmentar os domínios organizacional e doméstico.

Palavras-chave: Expatriados. Equilíbrio trabalho-lar. Limites. PE-Fit.

\section{Gestión de los límites entre trabajo y hogar: un estudio con expatriados}

\section{Resumen}

El objetivo de este estudio fue comprender las tácticas que utilizan los expatriados para administrar la interfaz entre los dominios trabajo y hogar. Este estudio cualitativo se realizó mediante entrevistas en profundidad con 64 expatriados brasileños y las entrevistas se analizaron por contenido. El estudio mostró que los expatriados manejan los conflictos que pueden aparecer en las relaciones con los actores sociales de los dominios organizacional (por ejemplo, empleadores, clientes y proveedores) y del hogar (cónyuge, hijos y padres) utilizando tácticas de trabajo límite. El análisis reveló una lista de tácticas que permiten a los expatriados integrar o segmentar los dominios de trabajo y hogar. Los autores sostienen que este estudio proporciona sugerencias de cómo los expatriados pueden interactuar activamente con las personas de los dominios del trabajo y el hogar de tal manera que puedan construir y mantener mejores relaciones laborales y hogareñas durante ese período exigente. Además, el estudio sugiere que las compañías desarrollen políticas de trabajo en el hogar que tengan en cuenta las preferencias que tienen un expatriado y su familia para integrar o segmentar los dominios de trabajo y hogar.

Palabras clave: Expatriados. Equilibrio trabajo-hogar. Límites. PE-Fit. 


\section{INTRODUCTION}

Working within international markets requires that organizations manage a global labor force. Expatriation is a practice commonly adopted by businesses to operate globally, but it is not free of challenges. For example, the period of overseas assignment is commonly characterized by an increase in the level of responsibility, work travel and stress in the professional life of the expatriate (Shaffer \& Harrison, 1998). Furthermore, increased stress is experienced in the home environment during this period, given the emotional vulnerability and the cultural conflicts to which the family is subjected in the host environment (Lazarova, Westman \& Shaffer, 2010). Taken together, these factors make the work-home conflict a theme of growing importance for the international management of human resources.

Given this context, several researchers have dedicated themselves to study, under different approaches, the conflict/balance between work and home experienced by executives in overseas assignments. The literature in this field has at times explored the organizational level, with analyses of the antecedents and consequences of the conflict between work and home (Beutell, 2010). Additionally, some studies have been performed at the individual level of analysis with qualitative approaches to understand expatriates' perceptions of work conflicts and what organizations can do to alleviate this problem (Fischlmayr \& Kollinger, 2010; Rosenbusch, Cerny II \& Earnest, 2015).

An analysis of the literature about the work-home conflict/balance of expatriates reveals some important gaps. First, it is necessary to understand the role of the expatriate's choices with regard to conflicts between work and home. Despite the importance of organizational incentives and contextual factors (Brewster, Wood \& Brookes, 2008), individuals are not automated reactants; they have an active role in this process, and their experience in the creation of the work-home conflict state should be better studied (B. Araujo, Teixeira, Cruz \& Malini, 2014; B. Araujo, Tureta \& D. Araujo, 2015; Felix \& Cavazotte, 2019). Second, there is a need to broaden the emphasis of the conflict or the problem experienced for the solution adopted by the individuals in question (Felix, Mello \& von Borell, 2018). Together, these gaps reveal an opportunity to analyze at the micro level of individual action how the balance between work and home is established by executives on overseas assignments (Dimitrova, Chia, Shaffer \& Tay-Lee, 2020; Gomes \& Felix, 2019).

Thus, the aim of this study is to understand the tactics that expatriates adopt to manage the interface between work and home domains during the period of their overseas assignment. A qualitative study was performed by in-depth interviews with 64 Brazilian expatriates from four different organizations. The present study provides theoretical and practical contributions. It is the first effort that analyzes the individual-level tactics used by expatriates to encourage balance between work and home. The use of Person-Environment Fit (P-E Fit) (Hartmann, 1991) and Boundary Theory (Clark, 2000) perspectives as theoretical support is also an important innovation for the literature in international human resource management because these methods contribute to an improved understanding of the relevance of personal preferences in integrating or segmenting work and home experiences in the dynamics of managing the demands of the expatriate, the business and the family. In practical terms, this study describes a list of actionable tactics that could be used by expatriated executives to promote a work-home balance.

\section{The work-home interface during overseas assignments}

What is known so far about the changes that occur within the boundary between work and home during overseas assignments? The literature has demonstrated, generally, that the experience of expatriation often brings greater permeability to the boundaries between work and home (Capitano \& Greenhaus, 2018). In this section, we focus on analyzing what the literature has revealed with regard to the expectations of the organization and the family in relation to the expatriate during the overseas assignment and the organizational incentives and incentives of the expatriated individual to address eventual conflicts of expectations from the work and family groups.

What demands specifically related to work are normally added to the daily life of a professional as a result of expatriation? Previous studies report an increase in time spent on business trips (Shaffer \& Harrison, 2001), professional activities at atypical hours due to time zone issues (Harvey \& Napier, 2004; Lirio, 2014) and regular work activities in the host country (Lauring \& Selmer, 2015; Shaffer, Kraimer, Chen \& Bolino, 2012). These changes occur mainly due to the increase of the professional's 
responsibility during the expatriation, which often is a result of the greater distance between the headquarters and the smaller size of the foreign affiliates (Al Mazrouei \& Pech, 2015; Felix, Teixeira \& Balassiano, 2019; Mäkelä \& Suutari, 2011). The need to justify the financial investment in the expatriation, to assume the identity associated with the new position and to produce results that will advance their career after repatriation are also relevant work domain-associated psychological stresses for the expatriate (Mcnulty, Cieri \& Hutchings, 2013; Shaffer et al., 2012).

Expatriation also increases specific demands originating from the family domain. By entering into an international experience, the expatriate often becomes the only provider for the family, and his or her spouse usually assumes the role of household caretaker and gives up his or her career and financial independence (Cole \& Nesbeth, 2014; Linehan \& Scullion, 2001). Even spouses who did not work prior to expatriation encounter challenges, such as the loss of companionship with other family members and difficulties with the language and safety in the host country (Lazarova et al., 2010). For married couples who have children, the expectations from the domestic domain become even more impactful, given challenges such as the loss of companionship from friends and school and the uncertainties with regard to the children's identity formation; these concerns tend to increase parental responsibilities (Mahajan \& Toh, 2014).

Thus, given the importance of family relationships, an expatriate must handle work demands without harming their relationships with their spouse and children. Previous research suggests that family members must be supportive during this temporary assignment, for the good of the future of the family (Mäkelä \& Suutari, 2011, 2015). Additionally, these individuals expect more permeability between work and home, that is, family members expect to receive support during workdays and colleagues from work expect that the expatriate will work at night and on weekends. Expatriates also have their own expectations regarding the degree of permeability between work and home (i.e., some prefer to separate work and home, whereas other prefer to combine them). However, the fact that both family and work members expect that their demands can be satisfied puts the expatriate in a constant position of potential conflict.

In seeking to minimize the negative effects of unmatched expectations from the business and the family on the expatriate's performance, several organizations have adopted work-family-specific support practices (Selmer \& Lauring, 2014). The aim is to offer support for expatriates and their families such that these executives can better reconcile personal and professional demands overseas (Fischlmayr \& Kollinger, 2010; Visser, Mills, Heyse, Wittek \& Bollettino, 2016). Nevertheless, the effects of these programs are limited; there is evidence of recurrent unchanged practices and practices that are poorly adjusted to the local needs of the human resource management policies of multinational corporations (Cole \& Nesbeth, 2014). In addition, businesses that encourage incentives to improve work-home balance also frequently implement high involvement work systems for expatriates, which represents a paradox, given that the first tends to counteract the second (Brewster et al., 2008).

Given the limitations of the contributions of organizational actions on the promotion of balance between work and home, the need emerges to understand better how expatriates have sought to address this problem within their own fields of influence. Mäkelä and Suutari (2011) took important initial steps and explored individual strategies used by global careerists, such as moving away psychologically or physically from stressful situations, avoiding assignments that would bring excessive professional and family demands and making emotional efforts to accept certain conditions of global careerists. Given the relevance of the individual's actions in the co-construction of reality (Stryker, 1980), this is a promising line of research that merits deeper theoretical studies.

\section{Theoretical avenues for understanding the work-home balance of expatriates}

We base our theoretical advances on the discussion of how expatriates seek balance between work and home, applying two main theoretical frameworks: Boundary Theory and PE-Fit, which are presented in the following.

\section{Boundary Theory}

People create, support and adapt boundaries between different domains (e.g., home, workplace) to simplify and categorize the world in which they live (Ashforth, Kreiner \& Fugate, 2000). "Domain" is understood here as "a cognitive space of what is included within the boundary" (Kreiner, Hollensbe \& Sheep, 2006, p. 1319), and "boundaries" are symbolic co-constructions of 
a physical, temporal, or behavioral nature that distinguish one domain from another (Clark, 2000; Rau \& Hyland, 2002). These boundaries can be understood in a bipolar continuous dimension, in which on one extreme are the thin/weak boundaries and on the other are the thick/strong boundaries (Ashforth et al., 2000). When they create thin/weak boundaries, individuals allow the boundaries to be permeable and the domains to be integrated. Conversely, thick/strong boundaries encourage impermeability and segmentation between domains (Bader, Froese \& Kraeh, 2018; Hartmann, 1991).

These ideas opened new possibilities for the literature of work-home conflict/balance in domestic environments. Subsequent studies broadened the discussion (e.g., Ashforth et al., 2000; Clark, 2000; Kreiner, 2006) and showed that in home domains in which there is a preference for thin boundaries, the individual receives stresses based on interactions in the work schedule and space on the part of his or her family members. Professional activities performed in the family domain are observed as natural in this case. They also identified that the preferences for thin boundaries reveal an expectation that the times and spaces destined for home and family be distinct, which leads to reduced family interactions in the context of work and an exclusive dedication to personal and family subjects when in the home domain.

Because boundaries are constructed in the interactions between individuals and social groups (Stryker, 1980), it is possible that in an institutional domain, expectations are created with regard to the degree of permeability in relation to the other (B. Araujo et al., 2015; Cruz \& Meisenbach, 2018). Among groups such as a family or an organization, a relatively stable preference may develop for a more segmented or more integrated posture between the work and home domains. When confronted with the individual's expectations, these preferences reveal potential susceptibility to work-home conflict (Kreiner, Hollensbe \& Sheep, 2009). The P-E Fit approach is a theoretical lens that allows the analysis of the consequences of this interaction between the individual and the collective entities of family and work.

\section{PE-Fit}

We subscribe to the idea that P-E fit theory allows understanding of the interface between work and home as an environment of boundary management (Kreiner et al., 2009). One of the tenets of this theory, "preferences-supplies", maintains that when an environment or domain (in this article, work and home) satisfies the needs of the individual, fit is achieved (Kristof, 1996). In contrast, when the environment provides an excess or lack of the desired supplies, a mismatch occurs. According to P-E fit theory, fits or matches produce outcomes such as balance and well-being, whereas mismatches lead to stress or conflict (Kreiner et al., 2009). Thus, given the recurrent scenario of high expectations for boundary permeability from both work and home domains, expatriations can be interpreted as a period of high risks of mismatched demands and, as so, a period of potential work-home conflict.

In what ways does P-E theory allow us to advance the discussion about the work-home conflict/balance of expatriates? According to this perspective, integration between work and home is not inherently better or worse than segmentation between these domains (Kristof, 1996). We maintain, based on the work of Kreiner (2006), that individuals differ in terms of thinner or thicker preferences between work and home. Likewise, social entities that represent the work and home domains also express preferences for more integrated or more segmented boundaries. The incongruity between individual preferences (of the expatriate) and environmental (home and work) preferences is what creates susceptibility to boundary violations and, consequently, work-home conflict (Kreiner et al., 2009). The expatriate can take an active posture and is capable of co-constructing reality through interactions with the social actors present in the environment.

As such, our interest is directed toward understanding the micro-level actions or boundary dynamics (Weick, 1995) that expatriates adopt to manage the interface between work and home domains. It is important to highlight that the use of Boundary Theory and the P-E fit approach does not position the work-home balance as a point in the middle of a continuum; rather, it has work and home demands at opposite poles. Here, balance can be produced in two forms: a) when there is a match between the degree of integration/segmentation desired by the individual and the significant others from the work and home domains; and b) when, in the face of a boundary preference mismatch (P-E misfit), the individuals manage the boundaries so they can satisfy the demands from work and home. In this case, the individual obtains the psychological benefits of a boundary preference fit, even in a condition of work-home boundary preference. 


\section{METHODS}

We conducted 64 interviews with Brazilian expatriates sent to different countries. The following criteria were used to choose research participants. All participants were a) organizational expatriates, which are those sent by organizations for overseas assignments for a defined period (B. Araujo et al., 2014); and b) residing overseas on an assignment for at least 1 year; c) accompanied by a partner (spouse or significant other during the international mission); d) accompanied by children and; f) in a leadership position.

The unit of analysis was the interaction between the expatriates and the representatives of the family and home domains and was explored from the perspective of the expatriate regarding his actions. We limited the number of participants on the basis of theoretical saturation (Glaser \& Strauss, 1967). We only reported the tactics that were present in at least $20 \%$ of the interviews. Because we asked the interviewees to report only tactics that were successful, we understand that reporting tactics that were rarely used by the expatriates would decrease the reliability of the results. The interviews lasted on average 53 minutes and were transcribed and content-analyzed.

The data were collected from interviews conducted by video through a semi-structured script adapted from B. Araujo et al. (2015) in four Brazilian companies that have operations overseas. When the interviewees were not in their first international assignment, we encouraged them to answer with their collective experiences in mind. Box 1 shows sample questions from the interview protocol.

\section{Box 1}

\section{Sample questions from the interview protocol}

\begin{tabular}{|c|c|c|}
\hline Section & Theme & Sample questions \\
\hline 1 & $\begin{array}{l}\text { Challenges regarding work- } \\
\text { home balance }\end{array}$ & $\begin{array}{l}\text { What things in your expatriation experience do you find you need to work especially } \\
\text { hard on to balance? How do you balance them? }\end{array}$ \\
\hline 2 & $\begin{array}{l}\text { Individual preference for } \\
\text { integration/segmentation }\end{array}$ & $\begin{array}{l}\text { Some expatriates like to separate their work and home lives whiles others prefer to } \\
\text { integrate them. How would you describe yourself in that regard? } \\
\text { Do you ever do work at home? Does your family life ever enter into your work? Are } \\
\text { there particular things you actively try to keep separate?... integrate? }\end{array}$ \\
\hline 3 & $\begin{array}{l}\text { Environment (Family and } \\
\text { company) preference for } \\
\text { integration/segmentation }\end{array}$ & $\begin{array}{l}\text { Do your Family members have certain expectations placed on them because of their } \\
\text { relation to you? What effect does that have on your home life? Work life? Do you ever } \\
\text { feel compelled to manage others' expectations of your family? Do you have certain } \\
\text { expectations of your family? }\end{array}$ \\
\hline 4 & Boundary work tactics & $\begin{array}{l}\text { Do you have frequent interruptions (a) when at home; (b) while at work? Is it a problem? } \\
\text { Do you have tactics or strategies for dealing with that? } \\
\text { Do the demands of work ever take away from your home life? Do the demands of home } \\
\text { ever take away from your work life? } \\
\text { Are there certain people who either respect your work-home boundary or don't? Have } \\
\text { there been times when others did not respect the boundary you were trying to keep? } \\
\text { How did/do you deak with that? The context of expatriation brought you any specific } \\
\text { contingencies for how you deal with these issues? If so, what? } \\
\text { Have you found that there are certain things you can do maintain the work-home } \\
\text { boundary to your liking? }\end{array}$ \\
\hline 5 & Others & $\begin{array}{l}\text { Are there any other issues that you've thought of during our interview that you think } \\
\text { might be important for me to know about regarding the topics we've discussed today? }\end{array}$ \\
\hline
\end{tabular}

Source: Research data. 
Initially, we interviewed 64 male expatriates, and no new tactics were found after the $49^{\text {th }}$ interview. From a list of 22 tactics reported, 10 were reported in at least $20 \%$ of the interviews. Later, we interviewed an additional 15 female expatriates, and one tactic from the previous interviews was not present in this data collection; therefore, it was excluded from our list. Consequently, we finished the analysis with a final list of 9 boundary tactics.

The companies operate in the industrial segments of mining (2), energy (1) and steel (1). Companies in the industrial segment were chosen for the greater concentration of Brazilian expatriates in these organizations. As access was gained via formal requests to the global mobility departments of these organizations, it would be necessary to have organizations with a greater volume of expatriates to reduce access limitations. Each company supplied a list of expatriates who were willing to participate in the research, and the interviews were conducted in an order designed to maintain proportionality among the companies as to the measurements in which the interviews were conducted. There was a total of 79 interviews conducted by the same researcher. The participants were aged 33-40 (33\%), 41-55 (36\%) and over 55 years (31\%), and they were found in positions of middle management (55\%) and executive leadership (45\%).

In the content analysis process, an open grade of codification was used, which means that we did not consider previous categories in the processes of first and second order of code generation (Glaser \& Strauss, 1967). A set of tactics adopted by the interviewees was identified, and these were derived as follows. We grouped together data under first-order codes that we created with the goal of representing the action represented in each tactic. Then, we grouped the tactics found in second-order codes with the aim of classifying the tactics in systems of common meanings.

\section{RESULTS}

Our analysis of the data revealed 10 tactics used by expatriates to manage the interface between work and home during their overseas assignments. These tactics were organized in three categories of broader tactics (second-order codes), as shown below. After the name of each tactic, we reported the percentage of participants who offered at least one piece of empirical evidence that referred to the theme.

\section{Time-related tactics}

The first group of tactics refers to those in which the dynamics of boundary management are tied to the temporal perspective. In these tactics, underlying aspects are linked to the challenges associated with a different time zone, to the perspective of the transience of the international assignment and to the use of time to manage demands that are first stressed in one domain and then performed in another.

\section{Negotiating adaptation to time zones (42\%)}

This tactic refers to the challenge that several expatriates confront in interacting with social actors such as suppliers, customers, members of the company's headquarters, or family members who are located in different time zones. This scenario increases the demand for the permeability between work and home and the need to negotiate more segmented or more integrated boundaries to maintain more harmonious relationships.

I was expatriated in Japan, and our time zone in relation to Brazil is 12 hours different. My wife did not like that I worked at home, but you know you have to make exceptions for early morning meetings. I try to centralize these activities from $9 \mathrm{pm}$ to $11 \mathrm{pm}$ because it is early in one country and not yet dawn in another.

As may be observed in this tactic, the management of the interface between work and home occurs with family and work members to provide some level of integration between boundaries but, at the same time, to preserve some degree of segmentation such that the demands of both domains are met sustainably. 


\section{Obtaining temporary tolerance (75\%)}

Unlike what happens with self-initiated expatriates, those who are sent overseas by an organization have a previously defined term for a specific mission. This situation tends to create a perception of transience in managing the professional and family demands in this period. In the present study, we found that when the boundaries are unfit in relation to the preferences of the members of the work or home domain, the expatriates invoke an argument of transience to request greater understanding from the social actors with whom they interact in relation to the discomforts that they may face during this period.

I always went out of my way to distinguish work and personal matters. But, here, everything changed. I asked my wife and my children for an extra understanding only during this period, that here is an investment for our future.

I asked for authorization from the company to go to one of the therapy sessions with my son. The company was understanding, but is clear that this is for one time only, I was at the end of the expatriation when I asked.

In both cases, it was observed that the new demands found in the expatriation environment originating from the work and home domains meant that the boundaries that they routinely used to balance the interface between work and home no longer fit the environmental boundary preferences. Thus, some expatriates reported asking for greater temporary integration, but their default preference would be for segmentation. In other situations, the opposite happened. The fact that the expatriation had an end date was essential for both the expatriate and the family members and work supervisors to agree to adjust the type of boundary between the domains temporarily.

\section{Banking time (69\%)}

Some expatriates reported that they sought to address specific and greater-impact demands coming from work or from home by managing the volume of time devoted to each domain. Thus, when demands arise, there is a previously "accumulated credit" that allows them to perform a "withdrawal" without the state of harmony between those involved being broken.

In January, I knew that I would need to spend 3 weeks traveling in March. I mentioned this at home and immediately I arranged with them that I would see some movies with my children and make two short trips with my wife. It is how I was accumulating credits to make a withdrawal afterwards.

My wife had a child in the middle of our second year here abroad. I spent the entire first half of that year preparing myself to be able to dedicate myself more to her when my child was born. I did the same when he was about to enter school. I knew that I would need to give extra help to him.

In these cases, the expatriates managed, in a compensatory manner, the flow of energy between the home and work domains to achieve, in a longitudinal time perspective, the expectations of both domains. Instead of taking "loans" (requesting a flexibility to be paid back later), they were anticipating and investing time and energy in a specific domain so that the permeability of the boundaries was altered ahead of time to compensate for the expected future need without major inconveniences.

\section{Tactics related to physical space}

The second set of tactics refers to the process by which the boundaries are managed through a perspective of space. In this group of tactics, the management of physical boundaries such as enclosure doors, clothing and accessories to segment or integrate work and home is exhibited. Additionally, it also discusses how expatriates manage the distance between the work and home domains and use spaces not characterized as professional or familial to maintain a satisfactory management between the social actors involved. 


\section{Manipulating access (39\%)}

Because the demand for greater permeability between the work and home domains was shown to be intensified in expatriation, some activities are performed outside the spaces with which they are traditionally associated. For example, on occasion, the managers interviewed stated that they performed professional tasks at home and vice-versa. This by itself can be understood as a movement toward more permeable boundaries. Nevertheless, some expatriates stated that when they performed these activities, they sought to minimize the perception of boundary violation by visitors, as illustrated by the following excerpts from the interviews.

When I brought work home, I had the custom of keeping the door open or closed. Open is when I was doing something more relaxed, that the children could come in and stay with me, to converse. But, if I need to concentrate, I close the door, turn the "under construction" placard and they respect it. But, I cannot abuse it, I use it only in moderation.

To avoid controversy at work, when talking to my wife or to my children at work on something more personal, I close my door. When it is something very quick, there is no problem.

In this tactic, the door or placard located on the door signals to those involved the level of permeability of the boundaries between work and home allowed at that moment. Other acts such as going onto the balcony or into the backyard, settling down in a specific location, or playing pre-defined music were also noted as tactics that allowed one to communicate to social actors belonging to a domain that there is greater or lesser openness for interaction at a given moment.

\section{Using physical artifacts (35\%)}

Some interviewees reported using objects such as clothing and picture frames to communicate an intention of integrating or segmenting the home and work domains. They indicated the use of certain objects associated with home when they were at work and vice-versa when they wished to signal that they prefer boundary integration between these domains (e.g., picture frames with family photos at the workplace). Similarly, we also found reports of avoiding the use of these objects in the domain with which they are not typically associated (e.g., using specific key chains for work and home) to encourage more segmented boundaries between home and work.

When I arrive home and I need to work, I do not change clothes until finished. Everyone there at home knows and respects this. But, when I arrive and I change clothes, my son already knows that who is there is dad and no longer the executive.

At the beginning, I used to mix personal and professional matters more. I had a family picture frame and this would be an invitation to enter into my personal life. I liked it. But, then I removed it; I wanted to maintain more privacy.

These objects, by having shared meaning between the expatriates and the members of the home or work domains, acted as symbols of the boundaries between work and home and thus facilitated the communication of expectations for greater integration or segmentation at specific moments.

\section{Manipulating distance (52\%)}

According to some interviewees, physical proximity between the environments that characterize the home and work domains encourages integration between them, whereas a greater distance facilitates segmentation. Thus, by choosing the location of the residence and school for the children closer or more distant from the workplace, the expatriates establish integration or segmentation between work and home.

I wanted to live close to work. I wanted to be able to spend little time commuting and to have the flexibility to be able to go home or to work when I wanted. The gym and the children's school is also a radius of 200 meters from the house and the company and this helps me keep everything quite flexible. When I am stressed, I go to the gym and walk back. 
This statement show that in the interviewee' view, manipulating the distance between the home and work domains allowed them to construct boundaries of greater integration or segmentation. In some cases, events such as health problems in the family or the need to work on alternative schedules or days created greater demand for integration, which led those involved to reside and centralize personal activities in places near the workplace. Two interviewees reported that marriage crises motivated them to move themselves farther from work to facilitate segmentation between work and home and a greater dedication to the relationship with the wife.

\section{Exploring neutral spaces (70\%)}

This tactic is related to the use of spaces referred to by some interviewees as "neutral" for the fulfillment of professional or familial demands. Airports or hotel rooms were frequently noted as examples of these spaces. Some expatriates understood that, for example, when they were in a hotel on a business trip, it was not very clear to the company or the family to which domain that space belonged. As such, when they attended to a family requirement in this space, they would manage the expectation of the family member, suggesting that this was an exceptional permeability because they are in the work domain. In performing professional activities at night when traveling, for example, they suggest to the social actors of the work domain that it is also an exception because that space should be used for personal and family activities. Thus, this balance acknowledges those involved and encourages greater harmony in the relationships.

In the hotel, in the airport, nobody can say that they have priority. My family believes that work has the priority, and the company initially did not ask me for what I do in those places. Then, when I did something, I left it clear that I was being flexible and accountable in the relationship.

The hotel at night on the road is neither work nor family. It is me. But, as I have much to do with both, I use the theoretically occupied location to pay attention, but I emphasize that I am going the extra mile.

It is noted that in both cases, the expatriates positioned the segmentation both for home as well as for work as the default boundary for the situations in which they found themselves in these neutral spaces. The boundaries became integrated to the domain that the expatriate considers a priority in the circumstance and at any time the expatriate feels at ease to establish a segmented boundary again and perform another type of activity.

\section{Behavior-related tactics}

The third group of tactics refers to actions that involve adopted behaviors that allow one to manipulate boundaries to increase or decrease permeability according to the need presented in each situation. The actions identified involve the use of technologies, asymmetrical information and selection in interactions.

\section{Exploiting informational asymmetries (21\%)}

In this tactic, the interviewees stated that they experienced situations in which informational asymmetries occur in relation to other social actors in the home and work domains. This occurs, for example, when family members do not exactly know the workflow and individuals in the work domain are unfamiliar with the full details regarding what occurs in the home domain. Some expatriates stated that they make use of this informational asymmetry to establish more segmented boundaries between work and home.

I confess that I have said that I was much busier than I actually was to my family to gain their understanding so I could stay late at work.

I have already needed to tell the company that my daughter had a health problem to be able, in truth, to have an emotional time with my wife. I did not want to expose what was really going on with my wife, more of a marital issue. 


\section{Screening (67\%)}

Expatriates are subject to an increased demand for social interaction, and the data reveal that some interviewees used the help of other people to adopt a differentiated permeability between work and home, depending on the person or the topic that requires attention. For certain people or topics, the executive adopts segmented boundaries and asks that somebody, generally his wife or secretary, communicate his unavailability. However, for prioritized topics and people, they exhibit an integrated boundary.

My secretary already knows: she is to filter out. I am talking about when it is for health, only. For the rest, I ask her to say that I cannot talk right now. At home, it is the same thing: when it is some person who is not above me, I ask him or her to say that I am not available. Except when it is a monthly closing issue.

The tactics that were revealed in this session achieve the goal of the study to understand the tactics that expatriates adopt to manage the interface between work and home domains. Below, we present a discussion of the results compared to the literature about the work-home balance of expatriates.

\section{DISCUSSION}

In the present article, we explored the tactics that expatriates adopt to manage the boundaries between work and home. The work applied a theoretical framework already employed by Nippert-Eng (1996) and Kreiner et al. (2009) to study this phenomenon in a domestic labor context and, as expected, allowed for the identification of some tactics that seem more applicable to the environment of expatriation. For example, the constant geographic dislocation (Harvey \& Napier, 2004; Lirio, 2014) was characterized by the adoption of the "negotiating adaptation to time zones" tactic. The non-permanent character of expatriation (Mcnulty et al., 2013; Shaffer et al., 2012) serves as a backdrop for the "obtaining temporary tolerance" factor. The high volume of trips during expatriation (Shaffer \& Harrison, 2001), in turn, provides the conditions for the emergence of the "exploring neutral spaces" tactic. The fact that the expatriation situation leads to the establishment of relationships with social actors with whom there was no previous interaction provides likewise for the use of the "exploiting informational asymmetries" tactic. Thus, the results justify the idea presented here that the peculiarities of the expatriation environment required a specific study about the management of boundaries between home and work in the context of overseas assignments.

The perspectives of Boundary Theory (Ashforth et al., 2000) and of P-E Fit (Kristof, 1996) allowed relevant advances in relation to what was known in terms of the conflict/balance between work and home for expatriates. The results showed that expatriation required the construction of more permeable boundaries between the two domains, and this stress was even stronger with regard to the demands emerging from work. Despite the various statements noting the flexibility that some companies offered so that the expatriate could address family requirements, the expatriates seem to avoid the frequent use of this flexibility as a result of the need to justify the investment by the company and to create a positive reputation in consideration of their professional continuance after repatriation (Al Mazrouei \& Pech, 2015; Mcnulty et al., 2013; Shaffer et al., 2012).

On the part of the family, a posture of greater flexibility is noted, especially by the fact that many of the expatriates become the only providers for the family after starting the overseas assignment, which corroborates the findings of Cole and Nesbeth (2014). The statements suggest that the expatriates tend to prioritize the requirements of family members only when there are crisis situations, such as illness, threats of divorce, or problems with relationships with children. Several interviewees suggested that the use of the reported tactics helped to minimize the risk of possible relationship problems.

In conclusion, the active role assumed by the expatriate in the present study allowed for the expansion of the findings of the literature beyond the organization actions in relation to the work-home interface (Beutell, 2010) and beyond the conflict between these domains (Kempen, Pangert, Hattrup, Mueller \& Joens, 2015). It was possible to identify, at the micro level of social action, the management of boundaries that the expatriates perform and that allow them to minimize the negative 
consequences of possible inconsistencies between preferences regarding the boundary between work and home. This perspective is unprecedented in the field of conflict/balance between work and home in the context of expatriation and demonstrates the study's originality as well as its contribution to the expansion of empirical and theoretical knowledge on the topic.

\section{LIMITATIONS AND FUTURE RESEARCH}

The present study presents some limitations and opportunities for future research. First, the sample chosen for the study was restricted to Brazilian male expatriates, which limits the potential for transferability of the results presented. Thus, it is suggested that new investigations explore the tactics experienced specifically by female expatriates and those originating from nationalities and cultures in which, as opposed to that of Brazil, there is greater acceptance of permeability between the work and home domains. This would help broaden the non-exhaustive list of tactics presented in the present study.

Second, this study did not conceptually and empirically explore the conflict's direction that may be exhibited in work-to-home or home-to-work flows (Fischlmayr \& Kollinger, 2010). Future studies may analyze the expectations of the home and work domains regarding the permeability of the boundaries between work and home in both directions and allow for a greater understanding of the consequences of the preferences for segmented or integrated boundaries according to the flow of the relationship.

Third, we did not take into account the phase of expatriation, and we considered the phenomena under a homogeneous perspective over the long term. To overcome this limitation, it would be relevant to study whether and how the temporal evolution through the different phases of expatriation reveals patterns of tactics to balance work and home life that change over time. Fourth, we explored the experiences of organizational expatriates. We did not interview other types of expatriates, such as self-initiated expatriates (B. Araujo et al., 2014), international business travelers (Mäkelä \& Suutari, 2011) and flexpatriates (Adams \& van De Vijver, 2015). Thus, future research could explore their specificities and compare the boundary tactics adopted in different global employment contexts.

Finally, the study doesn't take into account the issue of work at home and global mobility from the perspective of the reproduction of capital in the contemporary world, whose process incorporates different forms of work, including the analogous to slavery. Thus, we suggest future studies with a critical approach that could explore such possibilities by verifying the consequences of the tactics that were described in this article. Taken together, these suggestions would lead to significant advances in what is known as the understanding of how individual actions at the micro level on the part of expatriates can lead to a greater balance between home and work domains.

\section{SUGGESTIONS FOR PRACTICE}

Expatriates, their families and organizations can learn practical lessons from the present study. Expatriates are the main benefactors of this study in terms of practical applications because the list of tactics presented here includes examples of tactics already used by individuals in an overseas assignment that could empower them to actively encourage a greater state of balance between work and home. To these individuals, it is suggested they reflect on their preferences and those of their family members and the company in which they work in terms of the permeability of boundaries between work and home.

Although the focus of this study was on the individual level of analysis, organizations can also learn from the results. Programs and incentives for the work-home balance of expatriates should take into consideration the preferences for segmentation and integration of the expatriated individuals, their families and the organization itself. This positioning is in contrast with the common belief in several organizations that the separation between work and home domains would be a desirable condition for a more balanced relationship. Our data suggest that organizations and leaders should realize that expatriates may have different preferences for integration or segmentation and should negotiate with them to co-construct more sustainable boundaries between work and home. 


\section{REFERENCES}

Adams, B. G., \& Van De Vijver, F. J. (2015, November). The many faces of expatriate identity. International Journal of Intercultural Relations, 49, 322-331.

Al Mazrouei, H. \& Pech, R. J. (2015). The expatriate as company leader in the UAE: cultural adaptation. Journal of Business Strategy, 36(1), 33-40.

Araujo, B. F. V. B., Teixeira, M. L. M., Cruz, P. B., \& Malini, E. (2014). Understanding the adaptation of organisational and self-initiated expatriates in the context of Brazilian culture. The International Journal of Human Resource Management, 25(18), 2489-509.

Araujo, B. F. V. B., Tureta, C. A., \& Araujo, D. A. (2015). How do working mothers negotiate the work-home interface?. Journal of Managerial Psychology, 30(5), 565-81.

Ashforth, B. E., Kreiner, G. E., \& Fugate, M. (2000). All in a day's work: Boundaries and micro role transitions. Academy of Management Review, 25(3), 472-91.

Bader, A. K., Froese, F. J., \& Kraeh, A. (2018). Clash of Cultures? German Expatriates' Work-Life Boundary Adjustment in South Korea. European Management Review, 15(3), 357-374.

Beutell, N. J. (2010). Work schedule, work schedule control and satisfaction in relation to work-family conflict, work-family synergy, and domain satisfaction. Career Development International, 15(5), 501-18.

Brewster, C., Wood, G., \& Brookes, M. (2008). Similarity, isomorphism or duality? Recent survey evidence on the human resource management policies of multinational corporations. British Journal of Management, 1(4), 320-42.

Capitano, J., \& Greenhaus, J. H. (2018). When work enters the home: Antecedents of role boundary permeability behavior. Journal of Vocational Behavior, 109, 87-100.

Clark, S. C. Work/family border theory: A new theory of work/family balance. Human relations, 53(6), 747-70.

Cole, N., \& Nesbeth, K. (2014). Why Do International Assignments Fail? Expatriate Families Speak. International Studies of Management \& Organization, 44(3), 66-79.

Cruz, D., \& Meisenbach, R. (2018). Expanding role boundary management theory: How volunteering highlights contextually shifting strategies and collapsing work-life role boundaries. Human Relations, 71(2), 182-205.

Dimitrova, M., Chia, S. I., Shaffer, M. A., \& Tay-Lee, C. (2020). Forgotten travelers: Adjustment and career implications of international business travel for expatriates. Journal of International Management, 26(1), 1-15.

Felix, B., \& Cavazotte, F. (2019). When a calling goes unanswered: exploring the role of workplace personalizations as calling enactments. Frontiers in psychology, 10, 1-14.

Felix, B., Mello, A., \& von Borell, D. (2018). Voices unspoken? Understanding how gay employees co-construct a climate of voice/ silence in organisations. The International Journal of Human Resource Management, 29(5), 805-828.
Felix, B., Teixeira, M. L. M., \& Balassiano, M. (2019). Who adapts better to Brazil: Expatriates from developed or Latin American countries? Revisiting cultural distance. International Journal of Cross-Cultural Management, 19(1), 71-84.

Fischlmayr, I. C., \& Kollinger, I. (2010). Work-life balance-a neglected issue among Austrian female expatriates. The International Journal of Human Resource Management, 21(4), 455-87.

Glaser, B., \& Strauss, A. (1967). The discovery grounded theory: strategies for qualitative inquiry. Abingdon, UK: Routledge.

Gomes, R., \& Felix, B. (2019). In the closet: a grounded theory of the silence of gays and lesbians in the workplace. Cadernos EBAPE.BR, 17(2), 375-388.

Hartmann, E. (1991). Boundaries in the mind: A new psychology of personality. New York, NY: Basic Books.

Harvey, M., \& Napier, N. (2004). The Impact of 'Global Time' on the Role of Expatriate Managers. Research and Practice in Human Resource Management, 12(1), 92-133.

Kempen, R., Pangert, B., Hattrup, K., Mueller, K., \& Joens, I. (2015). Beyond conflict: The role of life-domain enrichment for expatriates. The International Journal of Human Resource Management, 26(1), 1-22.

Kreiner, G. E. (2006). Consequences of work-home segmentation or integration: A person-environment fit perspective. Journal of Organizational Behavior, 27(4), 485-507.

Kreiner, G. E., Hollensbe, E. C., \& Sheep, M. L. (2006). On the edge of identity: Boundary dynamics at the interface of individual and organizational identities. Human Relations, 59(10), 1315-41.

Kreiner, G. E., Hollensbe, E. C., \& Sheep, M. L. (2009). Balancing borders and bridges: Negotiating the work-home interface via boundary work tactics. Academy of management journal, 52(4), 704-30.

Kristof, A. L. (1996). Person-organization fit: An integrative review of its conceptualizations, measurement, and implications. Personnel Psychology, 49(1), 1-49.

Kurki, T. (2014). Borders from the Cultural Point of View: An Introduction to Writing at Borders. Culture Unbound: Journal of Current Cultural Research, 6(6), 1055-70.

Lauring, J., \& Selmer, J. (2015). Job engagement and work outcomes in a cognitively demanding context: the case of expatriate academics. Personnel Review, 44(4), 629-47.

Lazarova, M., Westman, M., \& Shaffer, M. A. (2010). Elucidating the positive side of the work-family interface on international assignments: A model of expatriate work and family performance. Academy of Management Review, 35(1), 93-117.

Lirio, P. (2014). Taming travel for work-life balance in global careers. Journal of Global Mobility, 2(2), 160-82.

Mahajan, A., \& Toh, S. M. (2014). Facilitating expatriate adjustment: The role of advice-seeking from host country nationals. Journal of World Business, 49(4) 476-87. 
Mäkelä, L., \& Suutari, V. (2011). Coping with work-family conflicts in the global career context. Thunderbird International Business Review, 53(3), 365-75.

Mäkelä, L., \& Suutari, V. (2015). The Work and Personal Life Interface in the International Career Context: An Introduction. In L. Mäkelä, \& V. Suutari (Eds.), Work and Family Interface in the International Career Context (pp. 1-9). New York, NY: Springer.

Mcnulty, Y., Cieri, H., \& Hutchings, K. (2013). Expatriate return on investment in the Asia Pacific: An empirical study of individual ROI versus corporate ROI. Journal of World Business, 48(2), 209-21.

Nippert-Eng, C. E. (1996). Home and work: Negotiating boundaries through everyday life. Chicago, Illinois: University of Chicago Press.

Rau, B. L., \& Hyland, M. A. M. (2002). Role conflict and flexible work arrangements: The effects on applicant attraction. Personnel Psychology, 55(1), 111-36.

Rosenbusch, K., Cerny II, L. J., \& Earnest, D. R. (2015). The impact of stressors during international assignments. Cross Cultural Management, 22(3), 405-30.
Selmer, J., \& Lauring, J. (2014). Unhappy expatriates at work: subjective ill-being and work outcomes. European Journal of International Management, 8(6), 579-99.

Shaffer, M. A., \& Harrison, D. A. (1998). Expatriates' psychological withdrawal from international assignments: Work, nonwork, and family influences. Personnel Psychology, 51(1), 87-118.

Shaffer, M. A., Harrison, D. A. (2001). Forgotten partners of international assignments: development and test of a model of spouse adjustment. Journal of Applied Psychology, 86(2), 238-54.

Shaffer, M. A., Kraimer, M. L., Chen, Y. P., \& Bolino, M. C. (2012). Choices, challenges, and career consequences of global work experiences a review and future agenda. Journal of Management, 38(4), 1282-327.

Stryker, S. (1980). Symbolic Interactionism: a social structural version. Menlo Park, CA: Benjamin/Cummings.

Visser, M., Mills, M., Heyse, L., Wittek, R., \& Bollettino, V. (2016). Work-Life Balance Among Humanitarian Aid Workers. Nonprofit and Voluntary Sector Quarterly, 45(6), 1191-1213.

Weick, K. (1995). Sensemaking in organizations. Thousand Oaks, CA: Sage.

Marcos Roberto Nóbrega

ORCID: https://orcid.org/0000-0003-3036-6540

Master in Business. E-mail: mrnobrega@petrobras.com.br

Bruno Felix

ORCID: https://orcid.org/0000-0001-6183-009X

Ph.D. in Business Administration; Associate professor at Fucape Business School. E-mail: bfelix@fucape.br 